UDC 613.166: 612-001.19

DOI: $10.21668 /$ health.risk/2020.3.13.eng

Research article

\title{
HYGIENIC ASSESSMENT OF CONTRIBUTION MADE BY COOLING METEOROLOGICAL FACTORS INTO OCCUPATIONAL RISKS OF HEALTH DISORDERS FOR WORKERS WHO HAVE TO WORK OUTDOORS IN COLD SEASON
}

\author{
E.M. Polyakova ${ }^{1,2}$, A.V. Mel'tser $^{1}$, V.P. Chashchin ${ }^{1,2}$, N.V. Erastova ${ }^{1}$ \\ ${ }^{1}$ North-Western State Medical University named after I.I. Mechnikov, 41 Kirochnaya Str., Saint Petersburg, \\ 195067, Russian Federation \\ ${ }^{2}$ North-West Scientific Center for Hygiene and Public Health, 42 Sovetskaya Str., Saint Petersburg, 191036, \\ Russian Federation
}

\begin{abstract}
Effects produced by hazardous occupational factors on workers employed in oil extraction often occur under low temperatures when workers have to perform their tasks outdoors.

Our research goal was to assess a contribution made by cooling meteorological factors into health risks for workers performing their job tasks outdoors during a cold season in order to substantiate priority prevention activities.

The research was performed on workers employed by a large oil extracting company who spent different amount of time outdoors during a cold season. A posteriori group risk was assessed according to the Guide ${ }^{1}$ as per results obtained via periodical medical examinations in 2017-2018. Working conditions were assessed basing on a report obtained via special assessment of working conditions and industrial control results. Cooling microclimate was assessed according to G 2.2.2006-05 2 .

Basing on the results of a priori group risk assessment, work places were ranked as per health disorders probability. It was shown that in-plant noise was the leading factor causing health risks. Besides, when working experience exceeded 20 years, cooling meteorological conditions also made a substantial contribution into risks occurrence.

Obtained results indicate that it is necessary to develop medical and prevention activities for workers who have to spend a lot of time outdoors in areas with cold climatic conditions.

Key words: workers' health, health disorders prevention, hazardous working conditions, assessment o working conditions, risk assessment, occupational risks, risk management, outdoor work.
\end{abstract}

State guarantees aimed at providing health consider population safety as complete absence of unacceptable risks for life and health; any risk management has an ultimate goal which is consistent reduction in risks related to impacts produced by adverse factors on population, industrial and social infrastructure and environmental objects until such risks become acceptable [1]. Any labor or activity performed in industry and the environment involves probable adverse effects on health; their quantitative assessment is determined by

(C) Polyakova E.M., Mel'tser A.V., Chashchin V.P., Erastova N.V., 2020

Ekaterina M. Polyakova - Postgraduate Student at the Department for Preventive Medicine and Health Protection; Junior Researcher (e-mail: ustimenkoekaterina_2009@mail.ru; tel.: +7 (812) 303-50-00; ORCID: https://orcid.org/0000-0003-3493-4592).

Alexander V. Mel'tser - Doctor of Medical Sciences, Vice-Rector responsible for Regional public Healthcare Development and Medical Prevention, Head of the Department for Preventive Medicine and Health Protection (e-mail: Aleksandr.Meltcer@szgmu.ru; tel.: +7 (812) 303-50-00; ORCID: https://orcid.org/0000-0003-4186-457).

Valeriy P. Chashhin - Honored Scientist of the Russian Federation, Doctor of Medical Sciences, Professor, Head of the Research Laboratory dealing with Complex Problems of Hygiene and Epidemiology (e-mail: valerych05@mail.ru; tel.: +7 (921) 958-88-85; ORCID: https://orcid.org/0000-0002-2600-0522).

Natal'ya V. Erastova - Candidate of Medical Sciences, the Head of the Department for Analytical and Methodical Support for Regional Healthcare Development and medical and Prevention Activities (e-mail: nataliya.erastova@szgmu.ru; tel.: +7 (812) 303-50-00; ORCID: https://orcid.org/0000-0003-4062-9578).

${ }^{1}$ Occupational health risks for workers: guide. In: N.F. Izmerov, E.I. Denisov eds. Moscow, Trovant Publ., 2003, 448 p. (in Russian).

${ }^{2} \mathrm{G}$ 2.2.2006-05. The Guide on hygienic assessment of factors related to working environment and labor process. Criteria and classification of working conditions. Approved by the RF Chief Sanitary Inspector on July 29, 2005; came into force on November 01, 2005. KODEKS: an electronic fund of legal and reference documentation. Available at: http://docs.cntd.ru/document/1200040973 (03.04.2020) (in Russian). 
a value of a risk [2]. Occupational risks assessment as a component in the whole risk assessment system aimed at prevention and preservation of workers' life and health during their occupational activities is becoming more and more vital every year. It is to a great extent determined by changes that are happening now in the country including stronger competition on traditional goods, technologies, and labor markets. And new technologies tend to cause new health risks for workers [1, 3-6].

Obviously, occupational risks assessment is significant for enterprises operating in various brunches. As a tool applied to quantitatively assess levels of threats to health, it provides an opportunity to rank objects and workplaces and to determine priorities when accomplishing preventive activities taking into account actual risks levels. Risk assessment can give grounds for working out systems and means for individual and collective protection and determination of their efficiency as well as for finding solutions to other important tasks $[3-4,7,8]$.

Physical factors including vibration, noise, labor hardness, and unfavorable microclimate typical for certain seasons occupy the leading place among adverse occupational factors existing at oil-extracting enterprises [9]. A lot of technological processes and related work tasks involve a necessity for a worker to constantly or periodically stay either in a cold room without any heating or outdoors under dangerous exposure to cooling meteorological factors.

We should note that apart from low temperatures workers, as a rule, are exposed to a set of other adverse meteorological conditions (drops and rises in temperature, relative air humidity and mobility, precipitations, etc.); intensity of such factors is determined by climatic and geographic conditions existing in a region where a specific oil-extracting enterprise operates.

At present a considerable part of employable population in the West Siberia work in oil extraction. In most cases, workers employed in oil extraction are exposed to adverse occupational factors under specific natural and climatic conditions existing in the Polar region where cold season is long and air temperatures are low [10]. Unfortunately, despite technologies applied at oil extraction enterprises are constantly modernized and developed, it results in only slightly improved working conditions for oil industry workers. Moreover, working conditions assessments tend to neglect assessment of impacts exerted by microclimate on a human body on an open territory under exposure to cooling meteorological conditions [11].

At the same time, a role that microclimate plays in human activities is predetermined by the latter being possible only provided that temperature homeostasis is preserved and it is reached due to proper functioning of various systems in a body (cardiovascular, respiratory, endocrine, excretory system, energy, water-salt, and protein metabolism). Strain occurring in these systems functioning under exposure to adverse microclimate (heating or cooling one) can be a cause for body defenses inhibition and pre-pathology occurrence; they in their turn exacerbate effects produced by other adverse occupational factors. Consequently, there is a risk that morbidity will grow ${ }^{3}$. Therefore, in our opinion, the subject of the present work is vital and certainly worth considering.

Our research goal was to assess a contribution made by meteorological factors into occupational risks occurring when work tasks are performed outdoors in cold season and to substantiate priority of prevention activities.

Data and methods. There were 794 participants in our research; they were all workers employed by «Samotlorneftegaz» JSC, an oil extraction company. They had the following occupations: desalting and dewatering unit (DDU) operators; compressor units (CU) operators; operators responsible for working substance pumping into a bed (WSPB); repairmen. Working on an open territory (outdoors) was a criterion for selecting workers (occupa-

\footnotetext{
${ }^{3}$ Guide on occupational hygiene. In 2 volumes. Vol. I. In: N.F. Izmerov ed. Moscow, Meditsina Publ., 1987, 368 p. (in Russian).
} 
tions) to be included into the research. Workers from the examined occupational groups had to stay outdoors in cold season for different amounts of time. We created three occupational groups to analyze a contribution made by occupational factors into health risks occurrence. To properly compare occupational groups as per parameters characterizing workers' health depending on exposure to cold, we had to exclude impacts exerted by occupational factors existing only at certain workplaces and for workers with specific occupations and therefore being able to distort research results. Due to welding aerosol being a leading adverse occupational factor causing occupational pathology occurrence in electrogas-welders and repairmen, this occupational group was excluded from the overall sampling selected for a posteriori risk assessment [12].

Cooling microclimate outdoors and in cold rooms was assessed according to Guide $\mathrm{R}$ 2.2.2006-05. Equivalent temperature determination was based on daily meteorological parameters (air temperature and mobility) over three winter months (December 2018, January and February 2019) as per data obtained from Laryakskaya meteorological station. A posteriori group risk was assessed as per the Guide ${ }^{1}$ basing on data taken from the ultimate report on chronic diseases prevalence among workers employed at the examined enterprise as per results obtained via periodical medical examinations performed in 2017-2018. We calculated the following parameters: relative risk (RR), sensitivity (Se), specificity (Sp), and etiological fraction (EF) using contingency tables.

A priori occupational risks caused by exposure to in-plant noise, chemicals, overall vibration, labor hardness, and microclimate, as well as combined risks were assessed taking into account concentration/exposure dose and working experience. Working conditions were assessed basing on reports issued as per results of special assessment of working conditions and industrial control results. We took into account measured levels of in-plant noise and overall vibration, adverse chemicals contents in working area air (saturated aliphatic hydro- carbons), and factors related to labor process. All the examinations (measurements) were performed by laboratory centers certified according to established procedures. A priori occupational risk caused by exposure to adverse microclimate in cold season when work tasks were performed outdoors and in cold rooms was calculated basing on minimal air temperatures and average wind speed.

Data were statistically processed with OfficeStd 2013 RUSOLPNLAcdmc: 021-10232; and Statistica 10. Student's test and MannWhitney test were applied when parameters were distributed in stratified samplings. Discrepancies in the structure of qualitative properties distribution were assessed with $\chi^{2}$. A confidence interval being not lower than $95 \%(p<0.05)$ was taken as statistical reliability criterion.

Results and discussion. Adverse occupational factors can cause not only occupational diseases but also occurrence and development of common diseases related to an occupation [2]. Results of occupational risks assessment performed for workers from different occupational groups revealed that inplant noise was the leading factor causing both occupational and non-specific pathology development (Figure 1).

But still, there was just an insignificant probability that occupational pathology could develop due to exposure to overall vibration and factors related to labor processes at all workplaces of workers from the examined occupational groups.

Exposure to microclimate in cold (winter) season when work tasks were performed either outdoors or in cold rooms made a substantial contribution into occupational and nonspecific morbidity growth among workers regardless of their occupational group. We should note that according to the Guide $\mathrm{R}$ 2.2.2006-05, a territory where «Samotlorneftegaz» JSC is located belongs to the climatic zone II (III) (with average air temperature in winter being $-18^{\circ} \mathrm{C}$ and average wind speed calculated basing on the most probable values in winter months being $3.6 \mathrm{~m} / \mathrm{sec}$ ). Our results revealed that risks causedby exposure 


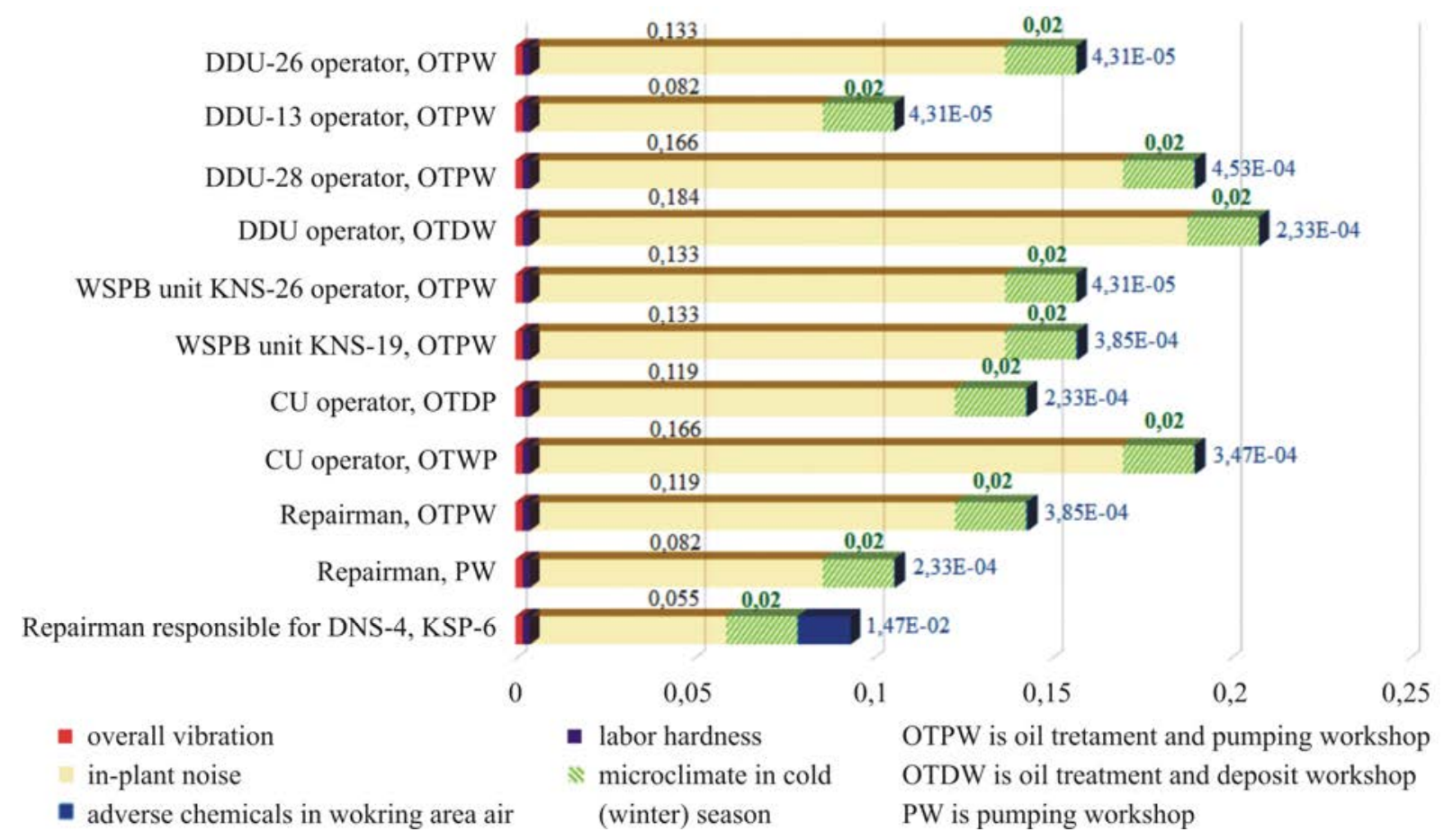

Figure 1. Contribution made by occupational factors into combined occupational risks occurrence over 10 years of working experience

to adverse microclimate in cold (winter) season amounted to 0.02 for workers with their working experience being equal to 10 years; it meant there was a conditional growth in morbidity equal to 2 cases per 100 workers for 10-year working experience. Values of a priori risks caused by exposure to cooling microclimate on an open territory determined that 20-year working experience was a significant one for non-specific pathology occurrence (Figure 1).

When working experience reaches 20 years, a contribution made by exposure to cooling meteorological conditions existing outdoors in cold season into health disorders increases and corresponds to conditional growth in morbidity equal to 5 cases per 100 workers. Exposure to adverse chemicals in working area air (aliphatic hydrocarbons), overall vibration, and labor process factors remains insignificant for occupational and non-specific pathology development.

When working experience reaches 40 years, risks caused by exposure to cooling meteorological conditions existing outdoors in cold season grow up to 0.33 and it corresponds to conditional morbidity growth equal to 33 cases per 100 workers.

Work places were comparatively characterized basing on calculated values of health risks over certain working experience. Working experience equal to 10 years was selected as an evaluative parameter. Working experience duration varied from 7 years (WSPB KNS-6 operator at oil treatment and pumping workshop No. 1) to 20 years (DDU operator at oil treatment and deposit workshop No. 1).

Basing on a priori group risk assessment, we ranked workplaces of workers from the examined occupational groups as per health risk probability. The highest rank place was taken by workplaces of DDU operators working in oil treatment and deposit workshop No. 1 (OTDW-1). It was due to value of combined health risks (caused by exposure to in-plant noise, overall vibration, adverse chemicals in working area air, labor hardness, and microclimate in cold (winter) season when work tasks were performed outdoors or in cold rooms).

The second rank places belonged to workplaces of CU VKS-28 operators and DDU DNS-28 operators working in oil treat- 
ment and pumping workshop No. 2 (OTPW-2). Combined risk amounted to 0.18 and it corresponded to a conditional growth in morbidity equal to 18 cases per 100 workers. The third rank place was taken by workplaces of WSPB operators working with KNS-19 and KNS-1 units in OTPW-2 and KNS-26 and KNS-13 in oil treatment and pumping workshop No. 1 (OTPW-1). Combined risks amounted to 0.15 and it corresponded to conditional growth in morbidity equal to 15 cases per 100 workers.

Figure 2 shows dynamics of changes in risks caused by exposure to in-plant noise and microclimate in cold season with working experience growing from 1 year to 40 years at workplaces of DDU operators working in oil treatment and deposit workshop No. 1 (OTDW-1).

As working experience becomes longer, risks of occupational and non-specific pathology is also rising. And it is interesting to note that exposure to cooling meteorological conditions leads to growth in risks. Thus, for example, when working experience of DDU operators working in oil treatment and deposit workshop No. 1 (OTDW-1) is equal to 20 years, risk of health disorders caused by inplant noise is equal to 0.245 , and health risk caused by exposure to adverse microclimate in cold season is equal to 0.05 , and totally it cor- responds to conditional growth in morbidity equal to 30 cases per 100 workers. When working experience was as long as 40 years, risks caused by exposure to microclimate in cold season grew substantially and amounted to 0.33 ; it corresponded to conditional growth in morbidity equal to 33 cases per 100 workers, and combined risks caused by exposure to both in-plant noise and microclimate in cold season reached 0.646; it corresponded to conditional growth in morbidity equal to 65 cases per 100 hundred workers (Figure 2).

Basing on accomplished time study of a working shift typical for the examined occupations, we distributed the examined workers into 3 groups as per different amount of time spent outdoors in cold season taking into account exposure to a set of adverse occupational factors; the groups were as follows: the $1^{\text {st }}$ one, $30 \%$ of a working shift spent outdoors; the $2^{\text {nd }}$ group, $50 \%$; the $3^{\text {rd }}$ group, 60-75\%.

Prevalence of chronic diseases among workers was analyzed taking into account amount of time spent outdoors during a working shift. As workers from the examined occupational groups had either 8- or 12-hour working shifts, a 40-hour working week was taken as an integral parameter; basing on it, we determined one risk group and two reference

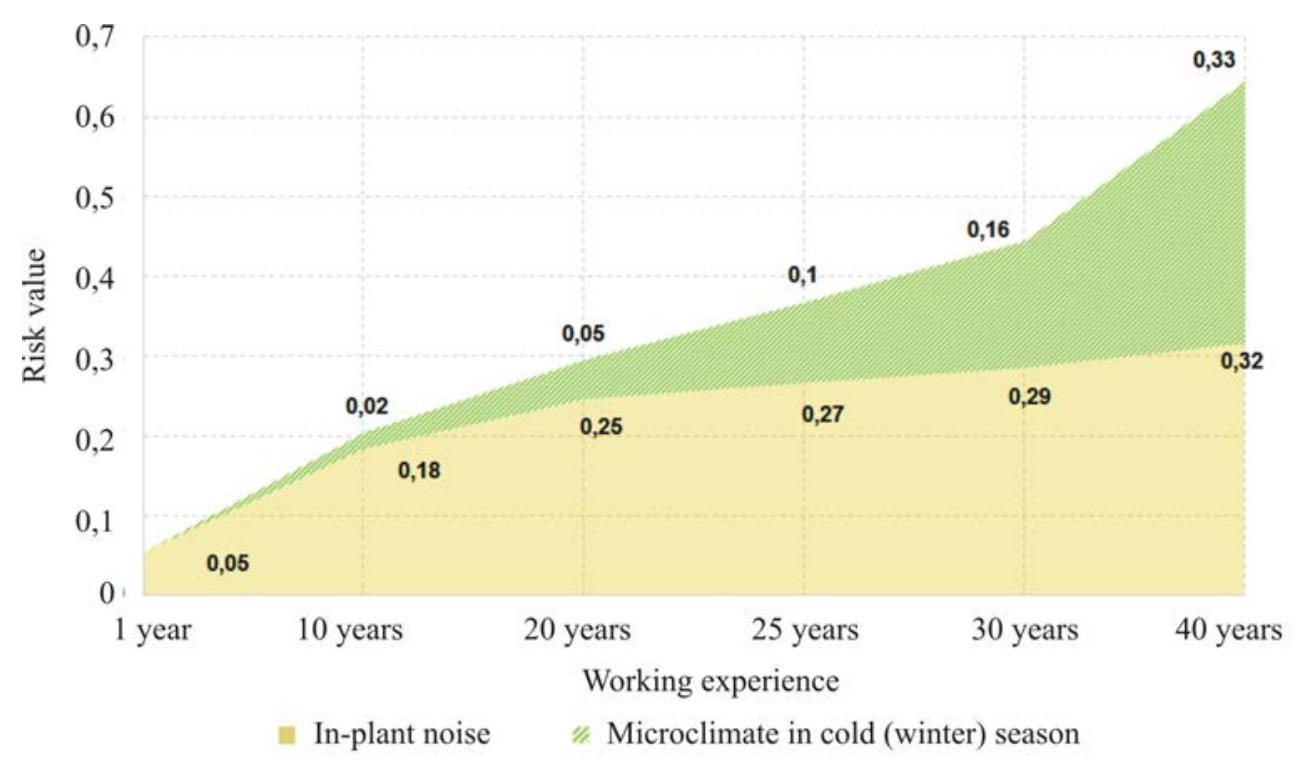

Figure 2. Occupational health risks caused by exposure to in-plant noise and adverse microclimate in cold season depending on working experience at a workplace of DDU operators working in oil treatment and deposit workshop No. 1 (OTDW-1) 
groups. The $1^{\text {st }}$ reference group was made up of CU operators and WSPB operators; workers from this group had to spend outdoors from 10.8 to 15.7 hours during a 40 -hour working week and it amounted to approximately $30 \%$ of the total working time. The $2^{\text {nd }}$ group included DDU operators who had to spend out doors from 18.5 to 20.05 hours during a 40-hour working week, and it amounted to approximately $50 \%$ of the total working time. The risk group was made up of repairmen who had to perform their work tasks mostly outdoors thus spending a lot of time on open territories; overall amount of time spent outdoors varied from 25.5 to 31 hours per a 40 -hour working week for this group.

All three groups were homogenous as per age and sex and there were no authentic discrepancies between them as per these parameters $(p>0.05)$. Male workers prevailed in all three groups.

Workers form the risk group had to spend authentically the longest amount of time outdoors, $28.4 \pm 0.2$ hours per a 40-hour working week in comparison with the $1^{\text {st }}$ and $2^{\text {nd }}$ occupational groups $(p<0.001)$. Average number of diseases per 1 worker $(0.4 \pm 0.06)$ was also authentically higher in the $3^{\text {rd }}$ (risk) group than in the $1^{\text {st }}(t=2.36 ; p=0.02)$ and the $2^{\text {nd }}$ one $(t=3$; $p=0.003)$. Also the share of practically healthy workers was the lowest in the $3^{\text {rd }}$ group $(70.4 \%)$ against the $1^{\text {st }}\left(\chi^{2}=5.07 ; p=0.025\right)$ and the $2^{\text {nd }}$ one $\left(\chi^{2}=10.3 ; p=0.02\right)$ (Table 1$)$.

We assessed a cause-and-effect correlation between health disorders and exposure to cold with different amounts of time spent outdoors; the assessment results are given in Table 2.

Obtained values of relative risks are higher than 1.0 with statistic significance being within $95 \%$ range; it means that diseases of the ear and mastoid, circulatory system diseases, digestive organs diseases, respiratory diseases and diseases of the nervous system can probably occur due to exposure to cold associated with long periods of time spent outdoors in cold season.

According to published data, the respiratory and cardiovascular systems take active part in thermoregulatory processes; it results in certain strain in them and determines specific structure of morbidity among workers. The most substantial shifts occur in the respiratory, blood-making, circulatory, immune, endocrine, reproductive, and nervous systems; there has been a concept designed specifically for such cases, namely, «polar» metabolic syndrome [13-19].

Relative risk (RR) shows how a risk of a specific outcomes grows (by how many times) in case there is an influencing risk factor against a situation when this influencing risk factor is absent ${ }^{4}$.

Relative risk (RR) calculation revealed an authentically high risk of nervous system diseases $(R R=4.66)$ among workers who had to spend the longest periods of time outdoors. Etiological fraction (EF) amounted to $78.5 \%$ and it meant that an extent to which those diseases were work-related was very high ${ }^{5}$.

Also workers form this group ran authentically high risks of digestive organs diseases $(\mathrm{RR}=3.96, \mathrm{EF}=74.7 \%)$, diseases of the ear and mastoid $(\mathrm{RR}=2.99 ; \mathrm{EF}=66.6 \%)$, and increased dextrose contents in blood $(\mathrm{RR}=3.55$; $\mathrm{EF}=71.8 \%$ ).

Sensitivity as a parameter shows a share of those who actually falls sick in a risk group; the fact that workers are sick is usually detected during periodical medical examinations and specificity parameter shows how probable is the correct identification of people who do not have any disease ${ }^{1}$. Specificity as per certain nosologies was rather high with the highest value being equal to $72.2 \%$ and it means a share of workers who fell sick and were detected as being sick during a periodical medical examination was significant in a risk group.

\footnotetext{
${ }^{4}$ Analyzing biomedical data with SPSS statistic software package: a manual. In: A.M. Grzhiboskiy, T.N. Unguryanu eds. Arkhangelsk, publishing house of the Northern State Medical University Publ., 2017, 293 p. (in Russian).

${ }^{5} \mathrm{G}$ 2.2.1766-03. Guide on assessing occupational health risks for workers. Organization and methodical basics, principles, and assessment criteria. Approved by the RF Chief Sanitary Inspector on July 24, 2003; valid since January 11, 2003. KODEKS: an electronic fund for legal and reference documentation. Available at: http://docs.cntd.ru/document/901902053 (16.09.2020) (in Russian).
} 
Table 1

Age and sex characteristics of workers from the examined occupational groups depending on working experience, number of diseases per 1 worker, number of practically healthy workers, and average amount of time spent outdoors in cold season $(M \pm m)$

\begin{tabular}{|c|c|c|c|c|}
\hline Parameter & $\begin{array}{l}\text { Group } 1 \\
n=201\end{array}$ & $\begin{array}{l}\text { Group } 2 \\
n=461\end{array}$ & $\begin{array}{l}\text { Group } 3 \\
n=132\end{array}$ & $\begin{array}{r}\text { Significance } \\
\text { of discrepancies }\end{array}$ \\
\hline Sex: males, abs. / \% & $140(69 \%)$ & $271(59 \%)$ & $131(99.2 \%)$ & \multirow{2}{*}{$p<0.001$} \\
\hline females, abs. /\% & $61(31 \%)$ & $190(41 \%)$ & $1(0.8 \%)$ & \\
\hline Average age, years & $38 \pm 0.6$ & $37.08 \pm 0.4$ & $36.06 \pm 0.8$ & $p>0.05$ \\
\hline Average working experience, years & $10 \pm 0.4$ & $9.8 \pm 0.3$ & $9.05 \pm 0.3$ & $p>0.05$ \\
\hline $\begin{array}{l}\text { Number of practically healthy } \\
\text { workers, abs. } / \%\end{array}$ & $163(81 \%)$ & $383(83.1 \%)$ & $93(70.4 \%) *$ & $\begin{array}{c}1 \text { and } 3: \\
\chi^{2}=5.07 ; p=0.025 \\
2 \text { and } 3: \\
\chi^{2}=10.3 ; p=0.02\end{array}$ \\
\hline $\begin{array}{l}\text { Average number of diseases } \\
\text { per } 1 \text { workers }\end{array}$ & $0.23 \pm 0.04$ & $0.21 \pm 0.02$ & $0.4 \pm 0.06^{*}$ & $\begin{array}{c}1 \text { and } 3: \\
t=2.36 ; p=0.02 \\
2 \text { and } 3: \\
t=3 ; p=0.003\end{array}$ \\
\hline $\begin{array}{l}\text { Average amount of time spent } \\
\text { outdoors in cold season during } \\
\text { a } 40 \text {-hour working week (hours) }\end{array}$ & $13.7 \pm 0.13$ & $20.7 \pm 0.13$ & $28.4 \pm 0.2^{*}$ & $p<0.001$ \\
\hline
\end{tabular}

$\mathrm{N}$ o t e : * means discrepancies are statistically significant as $p<0.05$.

Table 2

A posteriori risk assessment regarding health disorders among workers form the examined occupational groups with different amount of time spent outdoors

\begin{tabular}{|l|c|c|c|c|c|}
\hline \multicolumn{1}{|c|}{ ICD-10, nosologies } & $\begin{array}{c}\text { Relative risk (RR) } \\
(95 \% \mathrm{CI})\end{array}$ & $\begin{array}{c}\text { Sensitivity } \\
\text { Se, } \%\end{array}$ & $\begin{array}{c}\text { Specificity } \\
\text { Sp, \% }\end{array}$ & $\begin{array}{c}\text { Etiological } \\
\text { fraction EF, \% }\end{array}$ & Statistics \\
\hline Diseases of the ear and mastoid & $2.99(1.02-8.75)$ & 46.2 & 78.3 & 66.6 & $\begin{array}{c}\chi^{2}=4.40 ; \\
p=0.037\end{array}$ \\
\hline Diseases of the circulatory system & $1.99(1.00-3.96)$ & 56.7 & 52.0 & 49.8 & $\begin{array}{c}\chi^{2}=3.90 ; \\
p=0.046\end{array}$ \\
\hline $\begin{array}{l}\text { Increased dextrose contents in } \\
\text { blood }\end{array}$ & $3.55(1.40-9.01)$ & 70.0 & 62.3 & 71.8 & $\begin{array}{c}\chi^{2}=8.20 ; \\
p=0.005\end{array}$ \\
\hline Diseases of the digestive organs & $3.96(1.44-10.80)$ & 72.2 & 62.2 & 74.7 & $\begin{array}{c}\chi^{2}=8.40 ; \\
p=0.004\end{array}$ \\
\hline Diseases of the respiratory organs & $5.23(0.88-31.02)$ & 60.0 & 78.1 & 80.9 & $\begin{array}{l}\chi^{2}=4.15 ; \\
p=0.042\end{array}$ \\
\hline Diseases of the nervous system & $4.66(1.05-20.55)$ & 57.1 & 78.2 & 78.5 & $\begin{array}{l}\chi^{2}=4.98 ; \\
p=0.026\end{array}$ \\
\hline
\end{tabular}

Analysis of relative risk (RR) with statistic significance being within $95 \%$ confidence interval indicates there is a high risk of a disease due to exposure to cold as a risk factor as the parameter is higher than 1.0 both as per its average value, and its upper and lower limits.

\section{Conclusions.}

1. A priori occupational risk assessment allowed revealing that in-plant noise was the leading factor causing occupational and nonspecific pathology occurrence.

2. Cooling meteorological conditions existing on open territories in cold season also make their contribution into pathology development; this contribution grows considerably when working experience exceeds 20 years.

3 . Obtained values of relative risks with statistic significance being within $95 \%$ confi- 
dence interval are higher than 1.0; it means that diseases of ear and mastoid, circulatory system diseases, digestive organs diseases, respiratory diseases and diseases of the nervous system can probably occur due to exposure to cold associated with long periods of time spent outdoors in cold season.

Therefore, the results we obtained indicate that it is necessary to work out medical and preventive activities for workers who have to spend a lot of time outdoors in regions with cold climate. These activities should be aimed at preserving warmth within acceptable levels including workers being provision with additional heat-saving clothing and adapted work and rest regimes. Workers who perform their tasks under exposure to cold should be informed about its influence on a body and measures aimed at preventing overcooling. Besides, any performed hygienic assessment of occupational factors and factors related to labor process should take into account impacts exerted on a worker's body by climatic and weather conditions of a region where workers live and work.

Funding. The research was not granted any sponsor support.

Conflict of interests. The authors declare there is no any conflict of interests.

\section{References}

1. Zaitseva N.V., Popova A.Yu., May I.V., Shur P.Z. Methods and technologies of health risk analysis in the system of state management under assurance of the sanitation and epidemiological welfare of population. Gigiena i sanitariya, 2015, vol. 94, no. 2, pp. 93-98 (in Russian).

2. Shlyapnikov D.M., Shur P.Z., Alekseev V.B., Lebedeva T.M., Kostarev V.G. Methodological approaches to the integrated evaluation of the exposure and length of service in the occupational risk assessment. Gigiena i sanitariya, 2016, vol. 95, no. 1, pp. 33-36 (in Russian).

3. Mel'tser A.V., Erastova N.V., Kiselev A.V. Gigienicheskoe obosnovanie modelei kolichestvennoi otsenki apriornogo professional'nogo riska [Hygienic substantiation for models showing quantitative assessment of a priori occupational risks]. Profilakticheskaya i klinicheskaya meditsina, 2020, no. 3, pp. 12-20 (in Russian).

4. Krasovskii V.O. Algorithms of quantitative assessment of professional risks in occupational health. Norwegian Journal of development of the International Science, 2020, no. 38, pp. 28-32 (in Russian).

5. Bukhtiyarov I.V. Current state and main directions of preservation and strengthening of health of the working population of Russia. Meditsina truda i promyshlennaya ekologiya, 2019, vol. 59, no. 9, pp. 527-532 (in Russian).

6. Bukhtiyarov I.V., Denisov E.I., Lagutina G.N., Pfaf V.F., Chesalin P.V. Criteria and algorithms of workrelatedness assessment of workers" health disorders. Meditsina truda i promyshlennaya ekologiya, 2018, no. 8, pp. 4-12 (in Russian).

7. Simonova N.I., Nizyaeva I.V., Nazarov S.G., Zhuravleva E.A., Kondrova N.S., Stepanov E.G., Fasikov R.M., Grigor'eva S.M. [et al.]. Comparative analysis of occupational risk evaluation results through various methodic approaches. Meditsina truda i promyshlennaya ekologiya, 2012, no. 1, pp. 13-19 (in Russian).

8. Kurenkova G.V., Sudeikina N.A., Lemeshevskaya E.P. Methodical aspects of hygienic assessment of occupational risk to health workers. Sibirskii meditsinskii zhurnal (Irkutsk), 2015, no. 7, pp. 46-52 (in Russian).

9. Bakirov A.B., Gimranova G.G. Priority areas of science in extraction of oil, petroleum refining, petrochemical industry. Meditsina truda i ekologiya cheloveka, 2016, no. 3, pp. 5-10 (in Russian).

10. Karimova L.K., Kaptsov V.A., Salimgareeva T.M., Mavrina L.N., Gimaeva Z.F., Beigul N.A. Health risk assessment of violations of workers of enterprises of fuel and energy complex. Zdorov'e naseleniya i sreda obitaniya, 2017, vol. 289, no. 4, pp. 25-30 (in Russian).

11. Rakhmanov R.S., Gadzhiibragimov D.A., Bakhmudov G.G., Alikberov M.Kh., Tarasov A.V. On the evaluation of working conditions in open area in the winter season. Gigiena i sanitariya, 2019, vol. 98, no. 4, pp. 424-427 (in Russian). 
12. Mel'tser A.V., Polyakova E.M. Assessment of the combined professional risk working in open territory in the cold period of the year. Profilakticheskaya i klinicheskaya meditsina, 2019, vol. 72, no. 3, pp. 4-12 (in Russian).

13. Patologiya cheloveka na Severe [Human pathologies in the North]. In: A.P. Avtsyn, A.A. Zhavoronkov, A.G. Marachev, A.P. Milovanov eds. Moscow, 1985, 416 p. (in Russian).

14. Agadzhanyan N.A., Petrova P.G. Chelovek v usloviyakh Severa [A man in the North]. Moscow, KRUK Publ., 1996, 208 p. (in Russian).

15. Buganov A.A., Salamatina L.V., Umanskaya E.L. Prevalence of cardiovascular risk factors in various occupational groups of far north. Meditsina truda i promyshlennaya ekologiya, 2003, no. 2, pp. 1-6 (in Russian).

16. Karpin V.A. Medico-ecological monitoring of cardiovascular diseases in the urbanized north. Kardiologiya, 2003, no. 1, pp. 51-54 (in Russian).

17. Turchinskii V.I. Ishemicheskaya bolezn' serdtsa na Krainem Severe [Ischemic heart disease in the Arctic regions]. Novosibirsk, Nauka Publ., 1980, 280 p. (in Russian).

18. Kaznacheev V.P. Biosistema i adaptatsiya [Biosystem and adaptation]. Novosibirsk, Sovetskaya Sibir' Publ., 1993, 76 p. (in Russian).

19. Tkachev A.V., Klyarkina I.M. Sovremennye predstavleniya o vliyanii klimata Severa na endokrinnuyu sistemu cheloveka [Contemporary concepts of impacts exerted on the endocrine system by climatic conditions in the North]. Fiziologicheskie zakonomernosti gormonal'nykh, metabolicheskikh, immunologicheskikh izmenenii cheloveka na Evropeiskom Severe. Syktyvkar, 1997, pp. 6-17 (in Russian).

Polyakova E.M., Mel'tser A.V., Chashchin V.P., Erastova N.V. Hygienic assessment of contribution made by cooling meteorological factors into occupational risks of health disorders for workers who have to work outdoors in cold season. Health Risk Analysis, 2020, no. 3, pp.107-115. DOI: 10.21668/health.risk/2020.3.13.eng

Received: 10.07.2020

Accepted: 21.09 .2020

Published: 30.09 .2020 